\title{
Comparison of post placental IUD with interval IUD
}

\author{
Anjali Chhari*, Vijay Zutshi, Rachna Sharma, Swaraj Batra
}

Department of Obstetrics \& Gynecology, Maulana Azad Medical College, New Delhi, India

Received: 28 May 2015

Accepted: 06 June 2015

\section{*Correspondence:}

Dr. Anjali Chhari,

E-mail: chhari.anjali@gmail.com

Copyright: () the author(s), publisher and licensee Medip Academy. This is an open-access article distributed under the terms of the Creative Commons Attribution Non-Commercial License, which permits unrestricted non-commercial use, distribution, and reproduction in any medium, provided the original work is properly cited.

\begin{abstract}
Background: Generally IUD is being used as an interval method of contraception in our set up. This study was planned to compare the safety and efficacy of immediate post placental IUD and compare it with interval insertion in term of acceptance.

Methods: This was a prospective cohort study of 150 cases of reproductive age group women wanting to use temporary method of contraception. The cases were divided in three groups-Gp1-Post Placental insertion following normal vaginal delivery, Gp2-post placental insertion intra ceserean, Gp3 -Interval IUD. All were called for follow up at 6 wks, $3 \mathrm{mths}$ and $6 \mathrm{mths}$ after insertion. Statistical analysis was done by Chi-square test and Fisher's exact test.

Results: Various sociodemographic factors were comparable between these 3 groups. IUCD expulsion rate was highest in post vaginal delivery group $(12 \%)$ as compared to intraceserean $(0 \%) \&$ interval $\mathrm{CuT}(6 \%)$ which was statistically significant $(p-0.037)$.where as other complications like excessive bleeding ,pain ,infection ,medical removal in post placental CuT were almost similar to that of interval CuT with no statistical significance $(p-0.972)$. Neither pregnancy nor perforation reported in any of the groups.

Conclusion: Among the post placental group of insertion, intraceserean IUD was having nil expulsion rate.
\end{abstract}

Keywords: IUD, Post placental IUD, Intracesarean IUD

\section{INTRODUCTION}

Traditionally IUD in our set up has been used until 6wks post partum however use of post placental IUD had been reported since 1960 and gain popularity thereafter. ${ }^{1}$ Recently in India the use of post placental IUD is gaining popularity and clinical trials are being undertaken. ${ }^{2}$ Effective counseling and availability of a safe, economical and simpler contraception in immediate post partum period can decrease unintended pregnancies.

The present study was conducted to compare efficacy and safety of post placental IUD with interval IUD. The IUD used in this study was CuT 380 A which is provided free of cost by Ministry of Health and Family Welfare.

\section{METHODS}

This prospective study with the approval from departmental review board was conducted in Department of Obstetrics \& Gynecology at Maulana Azad Medical College and Associated Lok Nayak Hospital, New Delhi from Aug2011-Feb2013.

Total of 150 women of reproductive age group were enrolled for the study after counseling. The study population was divided into three groups. Group 1-post placental insertion following normal vaginal delivery (50cases), group 2-post placental insertion intra caesarean (50 cases) and group 3- interval method of insertion (50 cases). $\mathrm{Cu}$ T $380 \mathrm{~A}$ was used which is provided free of cost by govt. of India.

Inclusion criteria-desirous of CuT $380 \mathrm{~A}$ insertion, willing to sign an informed consent, willing to comply study protocol, reproductive age group women, willing for regular follow up.

Exclusion criteria-active pelvic inflammatory disease, uterine cavity anomaly, current carcinoma 
cervix/carcinoma in situ, chorioamnionitis, fetal demise, antepartum hemorrhage, ruptured uterus, eclampsia, prolonged rupture of membranes ( $>18 \mathrm{hrs}$ ), extensive genital trauma where repair would be disrupted by post placental IUD.

After vaginal delivery IUD was inserted by Kelly's forceps, while intra caeserean $\mathrm{Cu} \mathrm{T} 380 \mathrm{~A}$ placed at fundus manually and IUD thread was left in lower uterine segment without trimming the thread. Interval IUD was inserted by classical withdrawal technique. Strict asepsis was maintained during insertion in all three groups. All participants were called for follow up at $6 \mathrm{wks}, 12 \mathrm{wks}$ and $6 \mathrm{mths}$ interval. Various sociodemographic factors and complications were compared among these three groups.

The comparison of complications like expulsion, bleeding, pain, infection and medical removal were studied. Statistical analysis was carried out using the Chi -square test and Fisher's exact test with the use of SPSS 11.0.

\section{RESULTS}

Table 1: Distribution of demographic and obstetrics factors.

\begin{tabular}{|c|c|c|c|c|c|}
\hline \multicolumn{6}{|c|}{ Distribution of demographic and obstetrics characterstics } \\
\hline & Charecterstics & $\begin{array}{l}\text { Group } \\
1(\%)\end{array}$ & $\begin{array}{l}\text { Group } \\
2(\%)\end{array}$ & $\begin{array}{l}\text { Group } \\
3(\%)\end{array}$ & $\begin{array}{l}P \\
\text { value }\end{array}$ \\
\hline \multirow{2}{*}{ Religion } & Hindu & 52 & 54 & 62 & 0.761 \\
\hline & Muslim & 48 & 46 & 38 & \\
\hline \multirow{3}{*}{ Age } & $<20 \mathrm{y}$ & 4 & 4 & 0 & 0.031 \\
\hline & $20 y-35 y$ & 95 & 95 & 92 & \\
\hline & $>35 y$ & 1 & 1 & 8 & \\
\hline \multirow{3}{*}{ Parity } & 1 & 26 & 20 & 18 & 0.001 \\
\hline & 5 & 70 & 74 & 48 & \\
\hline & $>3$ & 4 & 6 & 34 & \\
\hline \multirow{4}{*}{ Living issue } & 1 & 26 & 20 & 18 & 0.341 \\
\hline & 2 & 44 & 66 & 48 & \\
\hline & 3 & 24 & 14 & 26 & \\
\hline & 4 & 6 & 0 & 8 & \\
\hline \multirow{2}{*}{ Booked } & Yes & 58 & 66 & NA & 0.346 \\
\hline & No & 42 & 34 & NA & \\
\hline \multirow{2}{*}{ POG } & $34 w k-37 w k$ & 4 & 0 & NA & 0.495 \\
\hline & $>37 w k$ & 96 & 100 & NA & \\
\hline \multirow{3}{*}{$\begin{array}{l}\text { Time of } \\
\text { counselling }\end{array}$} & ANC & 48 & 38 & NA & 0.264 \\
\hline & Early labor & 52 & 62 & NA & \\
\hline & Post partum & 0 & 0 & NA & \\
\hline \multirow{3}{*}{$\begin{array}{l}\text { Time since } \\
\text { ROM }\end{array}$} & $<6 \mathrm{hrs}$ & 94 & 84 & NA & 0.015 \\
\hline & 6-12hrs & 6 & 2 & NA & \\
\hline & $>12 \mathrm{hrs}$ & 0 & 0 & NA & \\
\hline
\end{tabular}

The study population consisted of 150 women who were divided into three groups each having 50 women. Various sociodemographic \& obstetrical characteristics (religion, age, parity, no. of living issues, booked or unbooked, period of gestation, time of counselling, time since rupture of membrane) were compared as shown in table 1. All the characteristics were comparable with no statistically significant difference showing that Hindu women were little more motivated for IUD insertion than Muslim women. Most of the women opting for IUD insertion were in the age group of 20-35 y, parity 2-4 and had 2 living issues at the time of insertion. In group 1 and group 2 women attending antenatal care (ANC) outpatient department (OPD) regularly were almost same as compared to those who were not regular in ANC visits. Among post placental group most of the IUDs were inserted in women who delivered at $>37 \mathrm{wk}$ period of gestation, only $4 \%$ delivered at $<37 \mathrm{wk}(\sim 35-36 \mathrm{wk})$ $(p-0.495)$.

Table 2: Distribution of complications at $6 \mathrm{wk}$ follow up.

\begin{tabular}{|c|c|c|c|c|}
\hline $\begin{array}{l}\text { Distribution of } \\
\text { up(6wks) }\end{array}$ & nplicati & s observ & during & low \\
\hline Complications & $\begin{array}{l}\text { Group } \\
1(\%)\end{array}$ & $\begin{array}{l}\text { Group } \\
2(\%)\end{array}$ & $\begin{array}{l}\text { Group } \\
\mathbf{3}(\%)\end{array}$ & $\begin{array}{l}P \\
\text { value }\end{array}$ \\
\hline Perforation & 0 & 0 & 0 & - \\
\hline Expulsion & 10 & 0 & 4 & $\begin{array}{l}1 \mathrm{vs} 3- \\
0.309 \\
\& 1 \mathrm{vs} \\
2-\mathrm{p}- \\
0.037\end{array}$ \\
\hline $\begin{array}{l}\text { Excessive } \\
\text { Bleeding }\end{array}$ & 4 & 4 & 2 & 0.802 \\
\hline Pain & 6 & 8 & 6 & 0.707 \\
\hline Infection & 4 & 2 & 0 & 0.648 \\
\hline Removal & 0 & 0 & 0 & \\
\hline Failure & 0 & 0 & 0 & - \\
\hline Strings not seen & 16 & 92 & 0 & 0.001 \\
\hline
\end{tabular}

Table 3: Distribution of complications at $12 \mathrm{wks}$ follow up.

\begin{tabular}{|lllll|}
\hline $\begin{array}{l}\text { Distribution of complications observed during follow up } \\
\text { (12wks) }\end{array}$ & $\begin{array}{l}\text { Group } \\
\text { Complications }\end{array}$ & $\begin{array}{l}\text { Group } \\
\mathbf{2 ( \% )}\end{array}$ & $\begin{array}{l}\text { Group } \\
\mathbf{3}(\boldsymbol{\%})\end{array}$ & $\begin{array}{l}\boldsymbol{P} \\
\text { Value }\end{array}$ \\
\hline Perforation & 0 & 0 & 0 & - \\
\hline Expulsion & 2.2 & 0 & 2.2 & 0.302 \\
\hline $\begin{array}{l}\text { Excessive } \\
\text { Bleeding }\end{array}$ & 2 & 2 & 4 & 0.802 \\
\hline Pain & 6 & 4 & 6 & 0.716 \\
\hline Infection & 0 & 0 & 4 & 0.495 \\
\hline Removal & 0 & 0 & 0 & \\
\hline Failure & 0 & 0 & 0 & - \\
\hline
\end{tabular}

Table 4: Distribution of complications at 6 months follow up.

\begin{tabular}{|lllll|}
\begin{tabular}{|l} 
Distribution of complications observed during \\
follow up (6mths)
\end{tabular} & $\begin{array}{l}\text { Group } \\
\mathbf{1}(\boldsymbol{\%})\end{array}$ & $\begin{array}{l}\text { Group } \\
\mathbf{2}(\boldsymbol{\%})\end{array}$ & $\begin{array}{l}\text { Group } \\
\mathbf{3}(\boldsymbol{\%})\end{array}$ & $\begin{array}{l}\boldsymbol{P} \\
\text { value }\end{array}$ \\
\hline Complications & 0 & 0 & 0 & - \\
\hline Perforation & 0 & 0 & 0 & \\
\hline Expulsion & 2 & 4 & 2 & 0.806 \\
\hline $\begin{array}{l}\text { Excessive } \\
\text { Bleeding }\end{array}$ & 2 & 2 & 4 & 0.821 \\
\hline Pain & 0 & 0 & 0 & \\
\hline Infection & 0 & 0 & 0 & \\
\hline Removal & 0 & 0 & 0 & - \\
\hline Failure & & & & \\
\hline
\end{tabular}




\begin{tabular}{|lllll|}
\hline Strings not seen & 0 & 84 & 0 & $<0.001$ \\
\hline
\end{tabular}

Table 5: Cumulative distribution of complications at follow up.

\begin{tabular}{|c|c|c|c|c|}
\hline \multicolumn{5}{|c|}{$\begin{array}{l}\text { Cumulative distribution of complications observed } \\
\text { during follow up }\end{array}$} \\
\hline Complications & $\begin{array}{l}\text { Group } \\
1(\%)\end{array}$ & $\begin{array}{l}\text { Group } \\
2(\%)\end{array}$ & $\begin{array}{l}\text { Group } \\
3(\%)\end{array}$ & $P$ Value \\
\hline Perforation & 0 & 0 & 0 & - \\
\hline Expulsion & 12 & 0 & 6 & $\begin{array}{l}1 \text { vs } 3- \\
0.309 \& \\
1 \text { vs } 2-p- \\
0.027\end{array}$ \\
\hline $\begin{array}{l}\text { Excessive } \\
\text { Bleeding }\end{array}$ & 8 & 10 & 8 & 0.972 \\
\hline Pain & 14 & 14 & 12 & 0.971 \\
\hline Infection & 4 & 2 & 4 & 0.972 \\
\hline Removal & 0 & 0 & 0 & \\
\hline Failure & 0 & 0 & 0 & \\
\hline Strings not seen & 16 & 88 & 0 & 0.001 \\
\hline
\end{tabular}

All the women were called at 6 wks, 12 wks and 6 mths for follow up. Cumulative follow up rates were close to $100 \%$ at $6 \mathrm{wks}, 98 \%$ at $3 \mathrm{mths}$ and $90 \%$ at $6 \mathrm{mths}$. Those who could not come for follow up were contacted on telephone and asked about the complications. During follow up visits women were asked about any fresh complaints post IUD insertion and examined. The comparison of complications among three groups at 6wks (Table 2), 12wks (Table 3) and $6 \mathrm{mths}$ (Table 4) is shown in respective tables. The complications like pain, bleeding, infection were comparable in all three groups ( $p$ value statistically insignificant) at all the visits. The expulsion rate was highest in group 1 but comparable to group $3(p-0.309)$ however no expulsion was observed in group $2(p-0.027$ statistically significant). The expulsion was seen in maximum number of patients at their first follow up visit. Similarly on examination, at first follow up visit strings were not visible in most of the group 2 women (92\%) as compared to group $1(16 \%)$ whereas strings were seen in all group 3 women ( $p$-0.001 statistically significant). Most of the missing strings were localized with ultrasonography while some strings were found coiled inside the cervical canal were pulled out gently and trimmed. In $84 \%$ women in group 2 strings were not visible even at their last follow up visit. No perforation or failure reported in any of the 150 women, proving high efficacy of IUD.

\section{DISCUSSION}

The post placental IUD insertion is common in number of countries like Mexico, Africa \& China. ${ }^{3-5}$ Our study is done to promote immediate post partum contraception in India, thereby improving the coverage of post partum contraception.

The results of our study indicate that immediate post partum insertion of IUD does not increase the amount of bleeding, pain, risk of infection .These findings and low rates of termination of pregnancy support the conclusion of other studies. ${ }^{6}$ One of the major concerns of post partum IUD is higher expulsion rates than interval IUD as also seen in our study. ${ }^{6}$ In this study expulsion rates were nil in intra cesarean group which was statistically significant ( $p$-0.037). A cohort study also found significantly lower expulsion rates at the time of cesarean delivery compared to vaginal delivery. ${ }^{7-9}$

In the present study, strings were not visible in $92 \%$ (at $6 \mathrm{wks}$ ) and $84 \%$ (at 6mths) women in group 2, which was statistically significant when compared to other two groups $(p-0.001)$ however the intrauterine presence of IUD was confirmed by ultrasound. In a prospective cohort study of 90 patients undergoing cesarean delivery only 32 women reported for follow up at $6 \mathrm{wks}$ and out of these strings were not visible at the time of examination in $72 \%$ women despite of the fact that they used ring forceps to place the strings into the cervix but ultrasound was used for localization of IUD. ${ }^{10}$ In present study during cesarean delivery IUD was placed manually at the uterine fundus and strings were left in the lower uterine segment as by Kelly O' Henley. ${ }^{11}$ The future studies may be directed to overcome this problem of missing strings when used as intra cesarean post placental IUD.

We did not encounter any uterine perforation in any of the group. Reports by other investigators also reinforce the reason to use IUD in immediate post partum period. ${ }^{11,12}$ Also fortunately we had no failure in our study.

\section{ACKNOWLEDGEMENTS}

We would like to thank Mrs. Kusum Chopra for statistical analysis and women who participated in the study.

Funding: No funding sources

Conflict of interest: None declared

Ethical approval: The study was approved by the Institutional Ethics Committee

\section{REFERENCES}

1. Grimes D, Schulz K, Van Vliet H, Stanwood N. Immediate post partum insertion of intrauterine devices(Cochrane Review). Cochrane Database Syst Rv. 2003;(1):CD003036.

2. Shukla M, Qureshi S; Chandrawati. Post placental intrauterine device insertion-a five year experience at a tertiary care centre in north India. Indian $\mathbf{J}$ Med Res. 2012;136(3):432-5.

3. Moran C, Fuentes G, Amado F, Higareda H, Bailon $\mathrm{R}$, Zarate A. Postpartum contraceptive practice in hospitals of the federal District. Salud Publica de Mexico. 1992;34:18-24.

4. Morrison C, Waszak C, Katz K, Diabate F, Mate EM. Clinical outcomes of two early postpartum IUD insertion programs in Africa. Contraception. 1996;53:17-21.

5. $\mathrm{Xu} \mathrm{JX}$, Reusche $\mathrm{C}$, Burdan A. Immediate post placental insertion of the intrauterine device; a 
review of Chinese and the world's experiences. Adv Contracept. 1994;10:71-82.

6. Welkovic S, Costa LO, Faundes A, de Alencar Ximenes R, Costa CF. Postpartum bleeding and infection after post placental IUD insertion. Contraception. 2001;63(3):155-8.

7. Chi I-c, Farr G. Postpartum IUD contraception-a review of an international experience. Advances in contraception. 1989;5:127-46.

8. Grimes DA, Schulz KF. Antibiotic prophylaxis for intrauterine contraceptive device insertion. Cochrane Database Syst Rev. 2000;(2):CD001327.

9. Celen S, Moroy P, Sucak A, Aktulay A, Danesman N. Clinical outcomes of early post placental insertion of intrauterine contraceptive devices. Contraception. 2004;69:279-82.
10. Levi E, Cantillo E, Ades V, Banks E, Murthy A. Immediate post placental IUD insertion at cesarean delivery: A prospective cohort study. Contraception. 2012;86:102-5.

11. Hanley KO, Huber DH. Postpartum IUDs: Keys for success Contraception. 1992;45:351-61.

12. Xu JX, Connell C, Chi IC. Immediate post partum IUD insertion in a Chinese hospital; a two year follow-up. Int J Gynaecol Obstet. 1991;8:281-90.

Cite this article as: Chhari A, Zutshi V, Sharma R, Batra S. Comparison of post placental IUD with interval IUD. Int J Reprod Contracept Obstet Gynecol 2015;4:1090-3. 